\title{
Genotypes and Clinical Data of Respiratory Syncytial Virus and Metapneumovirus in Brazilian Infants: A New Perspective
}

\author{
Adriana Gut Lopes Riccetto ${ }^{1}$, Luciana Helena Antoniassi da Silva ${ }^{2}$, Fernando Rosado Spilki ${ }^{3}$, André Moreno Morcillo ${ }^{1}$, Clarice \\ Weis Arns ${ }^{2}$ and Emílio Carlos Elias Baracat ${ }^{1}$ \\ ${ }^{1}$ Pediatrics Department, Faculty of Medical Sciences, State University of Campinas -UNICAMP; ${ }^{2}$ Department of Microbiology and \\ Immunology, Institute of Biology, State University of Campinas-UNICAMP; Campinas, São Paulo, SP; ${ }^{3}$ Institute of Health Sciences, \\ Unviversity Center FEEVALE; Novo Hamburgo, RS, Brazil
}

\begin{abstract}
The aim of this study was to determine if there was a correlation between respiratory syncytial virus (RSV) and metapneumovirus (MPV) genotypes and clinical data of Brazilian infants hospitalized for acute lower respiratory infection. The viruses in the patients' nasopharyngeal secretions were studied using the polymerase chain reaction and phylogenetic analysis. The study assessed 144 infants; $31.9 \%$ were RSV positive and 5.6\% were MPV positive. Statistical analysis was performed using the chi-squared test, Fisher's test, Odds ratio, univariate logistic regression, non-conditional multivariate logistic regression and the forward - stepwise method. Multivariate analysis confirmed a significant relationship between a positive PCR test for RSV and hospitalization during the month of May and with pulse oximetry less than $90 \%$. The phylogenetic analysis indicated the genotypes GA2, GA5, SAA1 (Group A), SAB1, SAB3 and BA (Group B) for RSV and Group B, subgroup B1, for MPV.

Key-Words: Respiratory syncytial virus, metapneumovirus, genotypes, infants, clinical.
\end{abstract}

Worldwide, acute viral respiratory infections are the most common disorder in infants, leading to a large number of hospitalizations every year [1]. It is known that $10 \%$ of all acute respiratory infections in this age group affect the lower airways [2]. The clinical evolution and presentation of these patients vary, but in more severe cases, such as respiratory failure, they are related to bronchiolitis and pneumonia. In spite of the low general mortality rate, infants with cardiac disease or infants born prematurely or with bronchopulmonary dysplasia are at increased risk of severe RSV disease [3]. In acute lower respiratory infections (ALRI), predominance of respiratory syncytial virus (RSV) and metapneumovirus (MPV) is observed in Brazil [4] and in other countries [5-7]. Besides using the immunofluorescence and culture methods for the etiological diagnosis of these infections, the polymerase chain reaction (PCR) is the most widely used test; it gives high sensitivity and specificity. Based on the PCR method, a molecular and phylogenetic analysis of the isolated virus can be performed, permitting classification into groups and subgroups. Several authors, from Brazil to China $[4,6,7,8]$, have performed these analyses, providing information on the worldwide circulation of RSV and MPV subgroups.

From a clinical viewpoint, viral etiology detection has advantages, such as identifying patients at risk, establishing contact isolation to prevent nosocomial infections and improved patient follow-up after discharge. Studies have demonstrated wheezing after the initial viral infection in many

Received on 10 July 2008; revised 17 December 2008.

Address for correspondence: Dr. Adriana Gut Lopes Riccetto. Rua Washington Luis, 752, Apt. 112, Americana - São Paulo - Brazil. Zip code: 13465-520. Telephone: (55-19) 34621514; Fax (5519)34065900. E-mail: a.riccetto@uol.com.br. This work used research resources of the Fundo de Auxílio à Pesquisa (FAEP) of the State University of Campinas - UNICAMP.

The Brazilian Journal of Infectious Diseases

2009;13(1):35-39. (C) 2009 by The Brazilian Journal of Infectious Diseases and Contexto Publishing. All rights reserved. patients, even when they are not characterized as atopic [9$11]$.

Several authors have tried to enumerate the clinical symptoms and epidemiological determinants of disease severity in patients with respiratory viral infections $[12,13]$. However, consistent clinical or epidemiological data indicating etiological diagnosis or poor prognosis are still not available $[4,14]$.

This study aims to identify respiratory syncytial virus (RSV) and metapneumovirus (MPV) in Brazilian infants hospitalized for acute lower respiratory infection and correlation of clinical data with viral genotypes, using the polymerase chain reaction and phylogenetic analysis.

\section{Material and Methods}

This was a prospective cohort study conducted in two university hospitals in Campinas, Sao Paulo, Brazil. Individuals responsible for the patients signed a term of informed consent. The project received the approval of the Research Ethics Committee, Faculty of Medical Sciences, State University of Campinas, and was assigned No. 076/2003 on April 15, 2003. The project also obeys the ethical principals of the World Medical Association and the Declaration of Helsinki.

The study population consisted of infants aged 0 to 12 months, hospitalized from April 1 to September 30, 2004, with a diagnosis of acute lower respiratory infection (ALRI), due to clinical symptoms such as tachydyspnea, altered breath sounds and pulse oximetry less than $95 \%$ in the surrounding air. The study excluded children who had a respiratory disease for more than seven days and those with hemodynamic instability, cardiac disease or chronic lung diseases.

The general data considered were: age in months, date of hospital admission and gender. The physical examination conducted on admission to the hospital checked heart and respiratory rates as well as atmospheric oxygen saturation and classified these data as normal or altered, according to 
the criteria set by the American College of Emergency Physicians and the American Academy of Pediatrics [15]. Mechanical ventilation need and duration was determined during hospitalization.

Nasopharyngeal secretions were collected during the first 24 hours after admission to the hospital by washing the nostrils with saline solution. The material collected was sent for analysis to the Laboratory of Animal Virology, Institute of Biology, State University of Campinas, UNICAMP.

Virus Isolation

All nasopharyngeal aspirates were inoculated in HEp-2 cell cultures for virus isolation. The specimens were inoculated in duplicate into preformed cell monolayers. Successive passages were conducted, always using Dulbecco's modified Eagle's medium supplemented with $2 \%$ fetal bovine serum (FBS) for dilution of the samples and maintenance of the cells. Typical cytopathic effects (CPE) were observed daily until seven days post-inoculation. Cultures that did not show CPE seven days post-infection were further submitted to at least six blind passages.

RNA Extraction and Viral Nucleic Acid Amplification

RNA was extracted from infected HEp-2 cultures using High Pure Viral Nucleic extraction kit ${ }^{\mathrm{TM}}$ (Roche Diagnostics ${ }^{\mathrm{TM}}$, Manheim, Germany). cDNA was synthesized using High Capacity cDNA kit (Applied Biosystems ${ }^{\mathrm{TM}}$, Foster City, USA). Both procedures were performed according to the manufacturer's instructions. All samples were investigated for RSV using amplification of specific genome fragments of the $G$ protein gene [16,17], corresponding to bases $151-173$ of the gene $\mathrm{G}$ protein [18-21] and for MPV using amplification of specific genome fragments of the $\mathrm{F}$ gene $[21,22]$.

Sequencing and Phylogenetic Analysis

PCR products were sequenced three times each, both in forward and reverse directions, using the ABI PRISM Big Dye Terminator Cycle Sequencing Ready Reaction kit (Applied Biosystems $^{\mathrm{TM}}$, Foster City, USA). BioEdit software, version 7.0.5.2 [23], was used to manipulate the retrieved nucleotide and amino acid sequences. The sequence alignments were performed using the Clustal W software, version 1.83 [24], using full alignment and 2000 bootstrap replications in order to ensure a high level of confidence in our analysis [24]. Phylogenetic analyses were performed using neighbor-joining as implemented in the MEGA version 4 software package [25], based on the Kimura two-parameter distance estimation method. Bootstrap re-sampling was performed for each analysis (500 replications). Reference nucleotides sequences were retrieved from the GenBank database [26]. The RSV and MPV nucleotide sequences that were obtained were submitted to GenBank.

The statistical analysis examined the relationship between the variables using the chi-square test, Fisher's exact test and, whenever required, the Odds Ratio and respective confidence interval. Univariate logistic regression was applied to obtain the total value of the Odds Ratio. The non-conditional multivariate logistic regression, the stepwise forward method with inclusion and the exclusion probability $p \leq 0.20$ and $p>0.05$, respectively, were applied to determine adjusted Odds Ratio values.

\section{Results}

We evaluated 144 infants; $59.7 \%$ were males, the mean age was four months and most of the cases occurred during the month of May (29.9\%). The viral research results, based on the PCR method, were negative in 90 patients $(62.5 \%)$, positive for RSV in 46 patients (31.9\%) and for MPV in eight patients (5.6\%). Regarding genotypes, 13/46 (28.3\%) belonged to Group A and 7/46 (15.2\%) belonged to Group B. In 26/46 RSV positive patients, it was not possible to determine the group and subgroup. The presence of the following genotypes was verified: GA2, GA5, SAA1 (Group A), SAB1, SAB3 and BA (Group B). In the study of the 144 patients, HMPV (Group B, subgroup B1) was found in eight patients. Co-infection was not observed in any of the positive patients (Table 1).

Pneumonia and bronchiolitis were found in the RSV/MPV negative, RSV positive and MPV positive groups. The distribution of radiological characteristics was similar in the three groups (Table 2).

In the univariate analysis, the association between the dependent variable (PCR+/PCR-) and the independent variables was evaluated by chi-square or Fisher's exact tests. The Odds Ratio values and the $95 \%$ confidence intervals $(95 \%$ $\mathrm{CI})$ were determined by univariate logistic regression. The data was processed with SPSS 7 (SPSS Inc., Table 3). In the multivariate analysis, we selected the variables with $\mathrm{p} \leq 0.25$ in the univariate the analysis: month of admission $(\mathrm{p}=0.005)$, cardiac frequency $(p=0.031)$ and pulse oximetry $(p=0.019)$. The final results were major risk for infants admitted to the hospital in the months of April (adjusted OR=5.13, [95\% CI 1.10-23.81] and May (adjusted OR=9.80 [95\% CI: 2.31-41.43]) and when the pulse oximetry was less than $90 \%$ (Adjusted OR=5.98 [95\% CI: $1.73-20.63, \mathrm{p}=0.004])$.

Unfortunately, the small number of samples with complete genotype analysis did allow a correlation between genotypes and clinical aspects. Preliminary descriptive data can be seen in Table 4.

\section{Discussion}

Assessment of the cohort revealed that the proportion of patients positive for RSV and MPV was similar to that of previously-published Brazilian studies. In these studies, this virus was present in $17.4-48 \%$ for RSV $[27,28]$ and MPV in 6.4 $-17.8 \%$ of the patients $[4,29]$.

Predominance of males less than six months and virus circulation is known to occur in autumn-winter seasons [30]. Pulse oximetry less than $90 \%$ was predominant in our RSV group, but no significant differences were observed in 
Table 1. Viral findings in a group of 144 Brazilian infants, by PCR and phylogenetic analysis.

\begin{tabular}{lcccc}
\hline Virus & PCR analysis & Genotype not determined & GroupAgenotype & Group B genotype \\
\hline RSV & 46 & 26 & Total: 13 & Total: 7 \\
& & & GA2: 5 & SAB1: 1 \\
& & & GA5: 7 & SAB3: 1 \\
MPV & 8 & 3 & SAA $1: 1$ & BA: 5 \\
Negative & 90 & - & - & B1:5 \\
\hline
\end{tabular}

Table 2. Radiological findings in negative, RSV positive and MPV positive groups, by PCR analysis.

\begin{tabular}{lcccr}
\hline PCR analysis & Pneumonia & Bronchiolitis & Pneumonia plus bronchiolitis & Total \\
\hline Negative & $11(12.2 \%)$ & $33(36.7 \%)$ & $46(51.1 \%)$ & 90 \\
RSV positive & $3(6.5 \%)$ & $20(43.5 \%)$ & $23(50 \%)$ & 46 \\
MPV positive & 0 & $5(62.5 \%)$ & $3(37.5 \%)$ & 8 \\
Total & $14(9.7 \%)$ & $58(40.3 \%)$ & $72(50 \%)$ & 144 \\
\hline
\end{tabular}

Table 3. Data on Brazilian infants, aged 0 to 12 months with acute lower acute respiratory infection, studied for RSV, using the PCR method.

\begin{tabular}{|c|c|c|c|c|c|c|}
\hline & \multicolumn{3}{|c|}{ PCR } & \multirow[t]{2}{*}{ OR } & \multirow[t]{2}{*}{$95 \%$ CI } & \multirow[t]{2}{*}{$\mathbf{p}$} \\
\hline & Positive & Negative & Total & & & \\
\hline \multicolumn{7}{|l|}{ Age (months) } \\
\hline 1 to 3 & 22 & 47 & 69 & 1.07 & $0.43-2.64$ & 0.432 \\
\hline 4 to 6 & 14 & 18 & 32 & 1.78 & $0.64-4.95$ & \\
\hline 7 to 11 & 10 & 23 & 33 & 1.00 & & \\
\hline \multicolumn{7}{|l|}{ Month of admission } \\
\hline April & 9 & 16 & 25 & 3.93 & $0.91-16.91$ & 0.005 \\
\hline May & 21 & 16 & 37 & 9.17 & $2.32-36.21$ & \\
\hline June & 10 & 23 & 33 & 3.03 & $0.73-12.55$ & \\
\hline July & 3 & 12 & 15 & 1.74 & $0.30-10.05$ & \\
\hline August and September & 3 & 21 & 24 & 1.00 & & \\
\hline \multicolumn{7}{|l|}{ Gender } \\
\hline Female & 18 & 36 & 54 & 0.92 & $0.44-1.92$ & 0.842 \\
\hline Male & 28 & 52 & 80 & & & \\
\hline \multicolumn{7}{|l|}{ Cardiac Frequency } \\
\hline High & 28 & 69 & 97 & 0.42 & $0.19-0.93$ & 0.031 \\
\hline Normal & 18 & 19 & 37 & & & \\
\hline \multicolumn{7}{|l|}{ Respiratory frequency } \\
\hline High & 27 & 53 & 80 & 0.93 & $0.45-1.93$ & 0.864 \\
\hline Normal & 19 & 35 & 54 & & & \\
\hline \multicolumn{7}{|l|}{ Pulse Oximetry } \\
\hline$<90 \%$ & 16 & 14 & 30 & 4.76 & $1.51-14.94$ & 0.019 \\
\hline $90 \mid-95 \%$ & 24 & 49 & 73 & 2.04 & $0.73-5.63$ & \\
\hline$\geq 95 \%$ & 6 & 25 & 31 & 1.00 & & \\
\hline \multicolumn{7}{|l|}{ Length of stay } \\
\hline$<5$ days & 18 & 36 & 54 & & & 0.842 \\
\hline$>5$ days & 28 & 52 & 80 & 1.07 & $0.51-2.23$ & \\
\hline \multicolumn{7}{|l|}{ Mechanical ventilation } \\
\hline Yes & 9 & 12 & 21 & 1.54 & $0.59-3.98$ & 0.370 \\
\hline No & 37 & 76 & 113 & & & \\
\hline
\end{tabular}

OR - Odds Ratio; 95\% CI - 95\% Confidence Interval; $\mathrm{p}$ - probability of Chi-square test. 
Table 4. Some clinical characteristics of Brazilian infants, with acute lower respiratory infection, studied for RSV and MPV, by PCR and phylogenetic analysis.

\begin{tabular}{|c|c|c|c|c|c|c|c|c|}
\hline Group & Subgroup & Boys & $\begin{array}{l}\text { Age }<6 \\
\text { months }\end{array}$ & $\begin{array}{l}\text { High cardiac } \\
\text { frequency }\end{array}$ & $\begin{array}{l}\text { High respiratory } \\
\text { frequency }\end{array}$ & $\begin{array}{c}\text { Pulse } \\
\text { oximetry } \\
<90 \%\end{array}$ & $\begin{array}{c}\text { Length } \\
\text { of stay } \\
>5 \text { days }\end{array}$ & $\begin{array}{c}\text { Mechanical } \\
\text { ventilation }\end{array}$ \\
\hline VSRA & GA2 & $3 / 5$ & $3 / 5$ & $4 / 5$ & $1 / 5$ & $0 / 5$ & $5 / 5$ & $1 / 5$ \\
\hline VSRA & GA5 & $4 / 7$ & $6 / 7$ & $5 / 7$ & $3 / 7$ & $2 / 7$ & $2 / 7$ & $2 / 7$ \\
\hline VSRA & SAA1 & $0 / 1$ & $1 / 1$ & $1 / 1$ & $1 / 1$ & $0 / 1$ & $0 / 1$ & $0 / 1$ \\
\hline VSRB & SAB1 & $1 / 1$ & $1 / 1$ & $0 / 1$ & $1 / 1$ & $1 / 1$ & $1 / 1$ & $0 / 1$ \\
\hline VSRB & SAB3 & $0 / 1$ & $2 / 4$ & $2 / 4$ & $1 / 4$ & $1 / 4$ & $2 / 4$ & $0 / 4$ \\
\hline VSRB & BA & $0 / 5$ & $2 / 5$ & $1 / 5$ & $1 / 5$ & $1 / 5$ & $1 / 5$ & $1 / 5$ \\
\hline MPV & B1 & $3 / 5$ & $3 / 5$ & $3 / 5$ & $2 / 5$ & $2 / 5$ & $1 / 5$ & $0 / 5$ \\
\hline
\end{tabular}

hospitalization length of time or need for mechanical ventilation (MV). The number of patients who required MV in this cohort study was similar to reports in the literature [31], being always less than $20 \%$ of the study population.

In the phylogenetic analysis, the placement of subgroup A of the RSV group was similar to what has been described from other countries over the last few years [30], in which the predominant subtypes were also GA2 and GA5. Concerning the other subgroups, subgroup BA is found globally, being reported in Japan [32], Kenya [33], Belgium [34] and the United States [35]; while subgroup SAB1 has been reported in Kenya and the United States and SAA1 and SAB3 was reported in South Africa [36]. Subgroup SAB3 is reported to be under study in Salvador, Brazil [37]. Regarding MPV, subgroup B1 found in this study sample had previously been reported in Australia [38] and South Africa [39]. Detailed data about phylogenetic aspects of this cohort can be seen in recent specific publications $[40,41]$.

Our purpose was to do correlate viral genotypes and clinical data. However, technical difficulties inherent to the process did not permit the identification of all positive PCR cases and correlation with clinical data. Future studies with a larger number of patients will be necessary to determine if there is a correlation between viral respiratory genotypes and clinical aspects in infants with acute lower respiratory disease.

\section{Conclusions}

The absence of epidemiological and clinical markers for RSV and MPV acquisition in infants reinforces the need for viral identification in studies on acute respiratory infections. Hypoxemia as an RSV/MPV infection marker is a warning sign of a serious clinical condition. PCR and viral genotype methods continue to be fundamental diagnostic tools for accumulating knowledge on the circulation of RSV and MPV in infant populations. This is the first Brazilian study attempt to correlate clinical characteristics and RSV/MPV genotypes. Further studies with a larger number of cases are required to improve knowledge on this subject, particularly involving several viral genotypes.

\section{References}

1. Shay D.K., Holman R.C., Newman D., et al. Bronchiolitis-associated hospitalizations among US children, 1980-1996. JAMA 1999; $282: 1440-6$.

2. Denny F.W. Acute respiratory infections in children: etiology and epidemiology (review). Pediatr Rev 1987;9:135-46.

3. Denny Jr F.W. The impact of respiratory virus infections on the world's children. In: Skoner DP. (Ed). Asthma and respiratory infections. New York, Marcel Deker, 2001.pp. 1-22.

4. Thomazelli L.M., Vieira S., Leal A.L., et al. Surveillance of eight respiratory viruses in clinical samples of pediatric patients in southeast Brazil.J Pediatr (Rio J). 2007 Sep-Oct;83(5):422-8.

5. Centers for Diseases Control and Prevention (CDC). Brief report: respiratory syncytial virus activity- United States, 2005-2006. MMWR Morb Mortal Wkly Rep 2006;55(47):1277-9.

6. Chan P.C., Wang C.Y., Wu P.S., et al. Detection of Human metapneumovirus in hopsitalized children with acute respiratory tract infrction using real-time RT-PCR in a hospital in northern Taiwan. J Formos Med Assoc 2007;106(1):16-21.

7. Bonroy C., Vankeerberghen A., Boel A., De Beenhouwer H. Use of a multiplex real-time PCR to study the incidence of human metapneumovirus and human respiratory syncytial virus infections during two winter seasons in a Belgian paediatric hospital. Clin Microbiol Infect 2007;13(5):504-9.

8. Syrmis M.W., Whiley D.M., Thomas M., et al. A sensitive, specific, and cost-effective multiplex reverse transcriptase-PCR assay for the detection of seven common respiratory viruses in respiratory samples. J Mol Diagn 2004 May;6(2):125-31.

9. Macartney K.K., Gorelick M.H., Manning M.L., et al. Nosocomial respiratory syncytial virus infections: the cost-effectiveness and cost-benefit of infection control. Pediatrics 2000 Sep;106(3):520-6.

10. Elphick H.E., Ritson S., Rigby A.S., Everard M.L. Phenotype of acute respiratory syncytial virus induced lower respiratory tract illness in infancy and subsequent morbidity. Acta Paediatr 2007 Feb;96(2):307-9.

11. Riccetto A.G.L., Ribeiro J.D., Silva M.T.N., et al. Late wheezing in infants after respiratory syncytial virus infection. Rev Paul Pediatria 2007;25(1);5-9.

12. Noyola D.E., Alpuche-Solis A.G., Herrera-Dias A., et al R.Human metapneumovirus infections in Mexico: epidemiological and clinical characteristics. J Med Microbiol 2005 Oct;54(Pt 10):969-74.

13. Brooks A.M., McBride J.T., McConnochie K.M., et al. Predicting deterioration in previously heathy infants hospitalized with respiratory syncytial virus infection. Pediatrics 1999;104(3):463-7.

14. Kneyber M.C.J., Moons K.G.M., De Groot R., Moll H.Á. Prediction of duration of hospitalization in respiratory syncytial virus infection. Pediatric Pulmonol 2002;33:453-57. 
15. American College of Emergency Physicians; American Academy of Pediatrics. In: Strange GR (Ed). Advanced Pediatric Life Support (APLS). Curso de Emergência Pediátrica., Rio de Janeiro, Guanabara Koogan, 2001, pp 1-45.

16. Sanz M.C., Kew O.M., Anderson L.J. Genetic heterogeneity of the attachment glycoprotein $\mathrm{G}$ among group A respiratory syncytial viruses. Vir Res 1994;33:203-17.

17. Wertz G.W., Collins P.L., Huang Y., et al.. Nucleotide sequence of the $G$ protein gene of human respiratory syncytial virus reveals an unusual type of viral membrane protein. Natl Acad Sci USA 1985; $82: 4075-9$.

18. Sullender W.M., Sun L., Anderson L.J. Analysis of respiratory syncytial virus genetic variability with amplified cDNAs. J Clin Microb 1993;31:1224-31.

19. Zheng H., Peret T.C., et al. Strain-Specific Reverse Transcriptase PCR Assay: Means to Distinguish Candidate Vaccine from WildeType Strains of Respiratory Syncytial Virus. J Clin Microb 1996;34:334-7.

20. Parveen S., Sullender W.M., Fowler K., et al. Genetic Variability in the G Protein Gene of Group A and B Respiratory Syncytial Virus from India. J Cli Microb 2000;44:3055-64.

21. Peret T.C.T., Hall C.B., Schanabel K.C., et al. Circulation patterns of genetically distinct group A and B strains of human respiratory syncytial virus in community. J Gen Virol 1998;79:221-9.

22. Falsey A.R., Erdman D., Anderson L.J., Walsh E. Human Metapenumovirus Infections in Young and Elderly Adults. J Infect Dis 2003;187:785-90.

23. Hall T.A. BioEdit: a user-friendly biological sequence alignment editor and analysis program for Windows 95/98/NT. Nucl Acids Symp Ser 1999;41:95-8.

24. Thompson J.D., Higgins D.G., Gibson T.J. Clustal W: improving the sensitivity of progressive multiple sequence alignment through sequence weighting, position-specific gap penalties and weight matrix choice. Nucleic Acids Res 1994;22:4673:80.

25. Tamura K., Dudley J., Nei M., Kumar S. MEGA4: Molecular Evolutionary Genetics Analysis (MEGA) software version 4.0. Mol Biol Evol 2007;24:1596-9.

26. GenBank database; in:http://www.ncbi.nlm.nih.gov/Genbank/ index.html, 12/10/2007.

27. Diniz E.M., Vieira R.A., Ceccon M.E., et al. Incidence of respiratory viruses in preterm infants submitted to mechanical ventilation. Rev Inst Med Trop Sao Paulo 2005;47(1):37-44.

28. Cuevas L.E., Nasser A.M., Dove W., et al. Human Metapenumovirus and Respiratory Syncytial Virus, Brazil. Emerg Infect Dis 2003; $12: 1626-8$.
29. Do Carmo Debur M., Bordignon J., Duarte dos Santos C.N., et al. Acute respiratory infection by human metapneumovirus in children in southern Brazil. J Clin Virol 2007.

30. Vieira S.E., Gillio A.E., Miya C.R., et al. Sazonalidade do vírus respiratório sincicial na cidade de São Paulo, SP. Pediatria (São Paulo) 2002;24(1/2):73-4.

31. Purcell K., Fergie J. Driscoll Children's Hospital Respiratory Syncytial Database. Risk factors treatment and hospital course in 3308 infnts and young children, 1991 to 2002. Pediatr Infect Dis J 2004;23:418-23.

32. Sato M., Saito R., Sakai T., et al. Molecular epidemiology of respiratory syncytial virus infections among children with acute respiratory symptoms in a community over three seasons. J Clin Microb 2005;43:36-40.

33. Scott P.D., Ochola R., Ngama M., et al. Molecular epidemiology of respiratory syncytial virus in Kilifi district, Kenya. J. Med. Virol 2004;74:344-54.

34. Zlateva K.T., Lemey P., Moes E., et al. Genetic variability and molecular evolution of the human respiratory syncytial virus subgroup B attachment G protein. J Virol 2005;79:9157-67.

35. Trento A., Viegas M., Galliano M., et al. Natural history of human respiratory syncytial virus inferred from phylogenetic analysis of the attachment $(\mathrm{G})$ glycoprotein with a 60-nucleotide duplication. J Virol 2006;80:975-84.

36. Venter M., Mashi S.A., Tiemessen C.T., Schoub B.D. Genetic diversity and molecular epidemiology of respiratory syncytial virus over four consecutive seasons in South Africa: identification of new subgroup A and B genotypes. J Gen Virol 2001;82:2114-7.

37. Moura F.E.A., Blanc A., Frabasile S., et al. Genetic Diversity of Respiratory Syncytial Virus Isolated During an Epidemic Period from Children of Northeastern Brazil. J Med Virol 2004;74:15660 .

38. Mackay I.M., Bialasiewicz S., Jacob K.C., et al. Genetic Diversity of Human Metapenumovirus over 4 Consecutive Years in Australia. J Infect Dis 2006;193:1630-3.

39. Ludewick H.P., Abed Y., van Niekerk N., et al. Human Metapenumovirus Genetic Variability, South Africa. Emerg Infect Dis 2005; $11: 1075-8$.

40. da Silva L.H.A., Spilki F.R., Riccetto A.G.L., et al. Genetic variability in the G protein gene of human Respiratory Syncytial Virus isolated from the Campinas metropolitan region, Brazil. J Med Virol 2008; $80: 1653-60$.

41. da Silva L.H.A., Spilki F.R., Riccetto A.G.L., et al. Variant isolates of human metapneumovirus subgroup B genotype 1 in Campinas, Brazil. J Clin Virol 2008;42:78-81. 